\title{
5. Darlau: Origins and their significance for Atsabe Kemak identity
}

\author{
Andrea K. Molnar
}

\section{Introduction}

Membership in the former Atsabe domain is not separate from Atsabe Kemak identity. But in order to understand this identity relation, it is important to appreciate the Atsabe Kemak's relation to land and particularly to places of origin. Darlau Mountain is one such focus, one origin place, and the question of who is a 'true' Kemak with a legitimate Kemak identity is enmeshed with this particular place of origin. In this chapter, I discuss the centrality of the great mountain of Darlau in Atsabe Kemak discourse on Kemak origins and identity.

Within the former Atsabe domain, Darlau is the tallest mountain (about 2400 $\mathrm{m})$. Atsabe Kemak represent Darlau as the cosmic origin place where sky and earth were connected in the beginning of time when differentiation had not yet taken place. Darlau Mountain, as a place of origin, is often paired with or discussed in opposition to Atsabe Lau or Ramelau Mountain. Kemak people associate Ramelau with the dead, with funerary rites and the invisible villages of the ancestors, while they associate Darlau with living human descendants. ${ }^{1}$

According to myth, Darlau is the mountain where the origin village, Lemia, was founded by the first Kemak ancestors. Even the later invader who subjugated local related chiefdoms and amalgamated them into the larger Atsabe domain is legitimised through a connection to Darlau and the origin village there. The dispersal of settlements and the former small chiefdoms that emerged from these settlements, and thus made up the Atsabe domain, are elaborated upon by the Atsabe Kemak in relation to Darlau.

Darlau is also claimed as the site of origin for all sacred trees that, ordinarily, were not allowed to be cut down. In the ceremonial context of building origin houses, however, these trees are specifically utilised: ua, ora, taha buci and goru trees. In the myth of the origin of fire, the ancestor brings fire from the top of Darlau with a taha branch. Identification with Darlau is thus a significant aspect of Atsabe Kemak identity and a means by which they distinguish themselves in relation to other groups. Old origin villages that made up the Lemia chiefdom

1 See Molnar (2006) for discussion of the local concepts related to funerary rites and ancestors. 
were located on Darlau and are still visited once a year by descendants to clean the graves of the ancestors and to place offerings. Through origin stories, I will highlight each of these significant elements of Darlau for the Atsabe Kemak, particularly in relation to notions of authority, precedence and subordination (cf. Fox 1995, 1999). The argument reinforces Reuter's (2006a:13) point that in a traditional cultural context, Austronesian-speaking societies have constructed their sense of identity and legitimised their territorial claims to land and other resources by reference to local and sometimes regional origin narratives'.

Various ANU-based anthropologists have developed the concept of precedence for the comparative study of Austronesian societies. ${ }^{2}$ This group of anthropologists has suggested that a fruitful comparative study of Austronesian societies needs to focus on indigenous conceptions of origins. Fox (1988:15, 1995:214-28) labelled the different configurations in which this preoccupation appears as 'origin structures'. He proposed that the studies of 'origin structures' and of the systems of precedence they generate are useful forms of comparison across Austronesian societies. ${ }^{3}$ Two major issues in the study of precedence concern 'what validates precedence and what it confirms'. The study of origins in these societies sheds light on what precedence confirms, since it is only in relation to the past that precedence is justified (Fox 1994:106). Furthermore, 'it is necessary for participants in systems of precedence to be able to trace relations to prior events, structures and persons' (Fox 1994:106). 'Context is paramount in the application of precedence...It is multivalued... [and] precedence can be used to create hierarchies, to dispute them, or simply undermine their creation' (Fox 1994:106). Relations of precedence among the smaller chiefdoms encompassed by the former Atsabe domain are expressed in origin myths in relation to specific places of origin and the dissemination of settlements from such places of earlier origin. One way the Kemak define their cultural identity is through their relation to the Darlau, particularly to the first origin village, Lemia, and the first chiefdom that coalesced there. Origin stories are significant among the Atsabe Kemak in narrating the past in relation to the local topography and landscape, and indeed in connection with the ordering of social relations within the former Atsabe domain in relation to specific places within their locality (cf. Fox 1997). The origin village and Darlau Mountain serve as significant metaphors for 'Kemakness'. While origin houses serve as the pivotal nexus of all marriage alliances that weave together the larger social fabric of a former domain, hierarchical relations among the component chiefdoms (the current main villages) are expressed in relation to origins from Lemia and Darlau. A relation to this mountain and to other significant places in the landscape is

2 See, for example, Fox (1988, 1989, 1994); Graham (1991); Grimes (1990); Lewis (1988); McWilliam (1989); Vischer (1992).

3 The concepts of hierarchy and precedence are discussed by Fox in a number of publications. See, for example, Fox (1993, 1994:1-22, 1996a, 1996b). 
central in the narratives and local discourse on identity and intra-group relations and thus social reproduction. Various previous studies (for example, Fox 1997; Reuter 2006b) have highlighted the ways Austronesian cultures relate to place and the landscape in encoding their memories of place as an 'origin' structure, a 'metaphor for living' (cf. Fox 1980a:333).

Before proceeding to a background discussion on the Kemak of Atsabe, I wish to clarify the ways I will use the terms domain, and chiefdom and domain. Chiefdom and domain refer to a hierarchical, centralised political organisation of varying size with a formal leader: a chief or ruler. Domain refers to the extent of the territory over which a ruler or chief had authority. The heads of these various domains had different titles. The ruler of the Atsabe domain held the title of koronel bote; other lesser domains were headed by figures that held the ranked titles of nai, dato and rati.

While kin relations were recognised among the various chiefdoms that derived from the original Lemia chiefdom on Darlau, they were completely autonomous in their authority over their chiefdoms' territorial domains and internal affairs. Once these chiefdoms coalesced into the Atsabe domain, the degree of autonomy of each chiefdom was affected - the authority of that chief had to be legitimised and confirmed by the rulers and the chiefs had to fulfil various obligations towards the ruler and the domain. Furthermore, the individual chiefdoms ceased to be territorially expansionist. The Atsabe domain, however, engaged in the expansion of its territorial domain that brought under its authority other groups, some of which were not Kemak. I shall elaborate further on the hierarchical organisation of the Atsabe domain in a later part of this chapter.

\section{The Kemak of Atsabe}

The Kemak-speaking group of Timor-Leste is found in the Bobonaro, Ermera and Ainaro districts. Very few professional anthropological studies existed on the Kemak ${ }^{4}$ (Barnes 1985; Clamagirand 1971, 1972, 1975, 1980, 1982; Hicks 1986) until a few years ago. Before I discuss the Atsabe Kemak, I acknowledge what remains the classic study of East Timorese Kemak culture, focusing on the Marobo Kemak. Clamagirand produced one superb monograph and four articles, based on her fieldwork undertaken between 1966 and 1970. Clamagirand's work is the basis for other comparative analysis of Kemak social practice (for example, Barnes 1985; Fox 1996b; Hicks 1986). The Marobo Kemak community members as described by Clamagirand (1982) are swidden cultivators with a

4 In the literature, various spellings have been used for the designation of this ethno-linguistic group, including Kema, Kemak, Ema and Quemaq. Molnar $(2004,2006)$ produced recent articles on the Atsabe Kemak based on ethnographic field research since 2002. 
social organisation that can be characterised as a 'house society' (see Fox 1993, 1996a). The house (uma) is the basic social unit and the focus of Marobo Kemak social organisation and relationships. The uma has a pivotal role in private and collective domains as well as in social organisation, ritual, myth and the indigenous belief system. The house defines an individual's place in the social hierarchy according to his or her house's place in the order of precedence (cf. Fox 1988, 1993a, 1993b, 1995, 1996b:130-53). Generalised exchange characterises Marobo marriage alliances that are contracted between and among houses. Clamagirand argues for a cyclical four-partner model of alliance. Houses are also arranged hierarchically around chiefdoms, thus having a significant role in local political organisation. Individual houses are also the focus of life-cycle rituals and private rites with the presence of both wife-takers and wife-givers, while collective rituals involve the entire community. Aside from the monograph produced on the Kemak, Clamagirand authored a number of articles, one of which focuses entirely on Kemak social organisation, and another on the house, both as a physical and as a social structure (her other articles focus on ritual and traditional weaving, respectively). While Clamagirand does not explicitly speak of local social organisation in terms of 'orders of precedence', her data appear to indicate the analytical significance and utility of this concept. Her ethnography, however, does not situate the Marobo in relation to other Kemak, such as the Atsabe Kemak, nor does she mention marriage alliances with major origin houses in Obulu and Boboe villages. The ethnography gives the impression that the Marobo are a 'self-contained unit' whose most enduring social relations are constructed within the Marobo community itself.

I encountered a similar attitude among the Atsabe Kemak towards the Marobo Kemak. There was very little emphasis on how Marobo fits into their Atsabecentrist view in which all Kemak originate from Darlau. In their view, the Marobo ancestors were the first to leave the origin village of Lemia and Darlau Mountain a very long time ago when the early Kemak people still lived on Darlau and had not yet dispersed and differentiated into various villages or chiefdoms. I did encounter a few comments that suggested negative attitudes towards the Marobo, depicting them in derogatory terms as rather backwards. Boboe and Obulo villages, however, never expressed any negative sentiments about the Marobo with whom they have close marriage alliances. They simply portrayed them as 'not true Kemak' since the Marobo tend to marry more within their own group and even more intensively with their Bunaq neighbours. The Marobo were viewed as marginal due to their lack of greater integration into the social fabric of component units of the former Atsabe domain. When I interviewed some Marobo people who were visiting their in-laws in Atsabe, they also tended to emphasise how they differed in customs and dialect from the Atsabe people. Atsabe Kemak recognise Marobo as the place of origin for weaving tais. Marobo people are viewed as the first people to plant cotton and to give cotton seeds 
to other regions. The Marobo are also considered to be among the first to make pottery for storage. Atsabe Kemak talk about them as 'different Kemak, since they are more like the Bunaq with whom they intermarried. Even their language [they mean dialect] is mixed with Bunaq words.' Obulo village of Atsabe subdistrict is considered to be Marobo since most of the named houses of Obulo are said to have derived from Marobo.

Clamagirand's ethnography does not situate the Marobo in the larger universe of East Timorese Kemak people in the sense of inter and intra-group relations with the populations outside Marobo. While I was unable to find references in Clamagirand's ethnography to the represented place of origin of the Marobo Kemak, or reference to the origin village of Lemia, the names of the main origin houses engaged in marriage alliance within Marobo provide clear indication of being branch houses (or 'descendant houses', ${ }^{5}$ as the Atsabe Kemak put it) of some of the oldest origin houses of Lemia. For example, uma Goru Ubu is the genitor house to a number of houses with $u b u$ in their name. More importantly, the oldest source house on Darlau, uma Tali Meta of Lemia, is a wife-giver to a multitude of Kemak source houses in many villages and is thus regarded by these source houses as their ai mea ('red tree or red trunk')-referring to the first marriage alliance established between two houses and the repetition of this marriage over generations. Uma Tali Meta has a branch house by the same name in Marobo, uma Talite (a dialectical variant of the name) (Clamagirand 1982:23). ${ }^{6}$ This can occur only if this house was founded by a family who were members of the original Tali Meta house of Lemia.

\section{Atsabe Kemak Origins}

The Atsabe subdistrict in Ermera district is the centre of the former Atsabe domain. There are 12 main villages, as has been indicated in the historical records of Portuguese colonial writing, with a new, thirteenth village that recently emerged as an official village in 2002. Some of the village names have changed over time, or rather the original village name is now retained only in the name of a hamlet.

\footnotetext{
5 'Descendant house' was expressed in terms of the relationship that exists between the source house (uma pun) and a house derived from it: 'child house' (uma ana).

6 This is not the place to go into naming 'origin houses', however, I do want to point out that a branched house will bear a part of the parent-house names - such as Goru Ubu of Lemia giving rise to Lulu Ubu; or Ilat Lara giving rise to Ilat Laun; or Soi Leki giving rise to Soi Lesu; Mali Ubu of Lemia giving rise to Mali Ubun Uma Dolen, and so on. I deliberately show the connection here between the oldest origin houses in Lemia and some of the main origin houses in Marobo (Clamagirand 1982:72).
} 
Atsabe contains the following villages

- Lemia Leten (upper Lemia), the origin village of all Kemak; Lemia Craic (lower Lemia) is now in a different administrative district - namely, Ainaro

- Laclo, one of the first to branch from the founding origin village of the Kemak from Lemia

- Boboe Leten and Boboe Craic (formerly one village, Boboe)

- Tiar Lelo (Ciar Lelo), which is central given its status as the village of the koronel bote, or the liurai of Atsabe

- Malabe (Atu Dame or Acu Dame in old writings)

- Obulo, whose population is related to the Marobo group and also heavily intermarried with Bunaq

- Paramin, with a mixed Kemak and Mambai population due to intermarriages

- Laçao

- Lau Buno

- Batu Manu

- Estado

- Atara

- Mali Mea, the new, thirteenth village, which branched off from Atara.

After Lemia on Darlau, the villages of Laclo, Tiar Lelo, Boboe and Malabe (Atu Dame) are viewed by the Atsabe Kemak as central given that all other villages are considered to be 'satellites' or offshoots of these four ${ }^{7}$ central villages (and former chiefdoms) with the same named houses present in the satellite villages. It must be pointed out, however, that Laclo, Atu Dame, Tiar Lelo and Boboe are considered to be branch settlements of Lemia with many of the same origin houses having a branch presence in these villages. It was also repeatedly stated that for major ritual occasions the populations of the 'satellite' villages convene at these four central villages. Along with Lemia, the four villages are also the nexus of the marriage and political alliances of the former domain of Atsabe.

Place, origin villages and named houses are the basic structuring units of groups, although in a couple of cases, such as those of Tiar Lelo and Boboe (Craic) villages, the first house's name (the house of the founder ancestor) is used in the same way as a clan or group name. Often this house encompasses the main source houses, each of which gives rise to, or encompasses, other named branch houses. Usually the first main house is the uma luli (sacred house, the repository of ancestral heirlooms as well as the focus for the rituals of the whole group). Named houses are the basic units of marriage exchanges and thus

7 Four central villages are Laclo, Tiar Lelo, Boboe and Atu Dame, thus not counting Lemia, the ultimate source village of all Kemak. The four focal villages made up the core of the Atsabe domain. 
anchor the highly complex nexus of alliances. There is a great emphasis on the founding village, the founding ancestor and the ordering of houses and social relationships in terms of both place and ancestor. There are many named houses but people tend to list the main source houses in the first instance since all other named houses derive from these main source houses. ${ }^{8}$

Topographically, most of the subdistrict is spread out on steep mountainous terrain with a few valleys. The great, rapidly flowing Kumubia River creates a border with the Letefoho subdistrict and features a beautiful waterfall (Bendera). The mountains of Atsabelau, Darlau and Ramelau are the most significant borders of the territorial domain ${ }^{9}$ and figure significantly in the ancestral belief system as well as origin stories. The great mountain of Darlau is considered to be the place of origin of all Kemak people.

In terms of local social organisation, the Kemak place great emphasis on founding villages and their associated founding ancestors. The hierarchical ordering of named source houses and social relationships is oriented to both place and ancestors. They extend out to the Mambai in Ailieu, the Bunaq and Tetun groups in the western part of Timor-Leste as well as in the Atambua region of Indonesian Timor. These alliances are still strongly maintained, particularly those within the sphere of power of the former domain of Atsabe. While most historical documents of the Portuguese era refer to regions within the current Atsabe subdistrict (Atsabe, Boboe, Obulo and Tiar Lelo) as separate domains (see, for example, Felgas 1956; Sherlock 1983), local constructions of social relations view the Atsabe domain as the all-encompassing unit whose authority subsumed that of Boboe and Obulo. With its centre at Tiar Lelo, it provided the line of the Atsabe rulers. Furthermore, there existed a specific order of precedence among these four domains. The authority of the Atsabe domain extended over all Kemak-speaking populations of Timor-Leste, covering a geographical distribution that, according to the Kemak, included not only the region of Atsabe in Ermera, but also most of northern Bobonaro, northern Ainaro and the Suai regions of Kova Lima. These assertions are based on migration and expansion through marriage and thus the foundation of new source houses. ${ }^{10}$

\footnotetext{
8 I did not start to find out about other named houses of the group until collecting genealogies and data on the marriage alliances.

9 Here the boundaries of the territorial domain of the original Atsabe domain are meant and not the much later expanded boundaries of the domain as claimed by the Atsabe Kemak.

10 In addition, I also recorded claims that the authority of the Atsabe domain was broadened through territorial expansion, and indeed, the domain had authority over the territorial domains of these other regions.
} 


\section{Contending Versions of Origin}

\section{Atsabe Origin Myths: Landscape and social relations - a connected earth and the sky}

Cuha is the vine that connected the earth and sky in the past. Earth and sky were connected by a huge, thick vine [cuha], and that way the people of the two realms could visit one another and God could talk directly to the people. The voices of the female sun and the male sun [Lelo Hine and LeloMane] were close in those days. The earth and the sky were linked on top of Darlau Mountain.

One day a man sent his wife to the top of Darlau to get fire, while he looked after the children. When the woman got to the top of the mountain, she heard beautiful music coming from the sky realm. The people in the sky were playing (pinging on) brass spiral armbands [lu' $u$ ]. The woman was so mesmerised by the music that she climbed up on the vine to the sky realm. It was already late at night and she still did not return. The children were crying as they were hungry. The husband was getting angrier and angrier and was very jealous. In anger, he started to sharpen a sacred heirloom sword. He was going to kill her. He sharpened and sharpened and tested it on his hand so that it was sharp enough. He then went up to the top of Darlau and in anger severed the vine connecting earth and sky. The sky flew up and up. That is why God's voice is too far away for us to hear and Lelo Hine, Lelo Mane no longer talk to us directly. Lelo Hine, Lelo Mane used to tell us what to do and how to do it if we had problems, like when we were sick. The sacred suri is still present. A chunk from the edge of the blade is missing. It broke off when the huge vine was chopped. The sacred sword that cut the vine is called siaka daka tai; it belongs to the luli [sacred] objects of Uma Mali $\mathrm{Ubu}^{11}$ in Lemia Leten village.

In this mythical representation of primeval times, the earliest Kemak ancestors lived together in the origin village of Lemia on Darlau, before sky and earth were separated and when humans and gods/spirits were not yet fully differentiated. The object that brings about the differentiation becomes a sacra (luli) of one of the oldest origin houses of the Atsabe Kemak in Lemia. The reference to Lelo Hine, Lelo Mane was further elaborated as follows.

Maromak created the ancestors and would visit with them. In ancient times, people could still see God. Maromak gave customs [lia hu'u] to

11 See house by same name in Marobo (Clamagirand 1982). 
the people and gave them sacred prayer beads [loi ana] so that during a funeral when praying with the loi ana, the soul of the deceased [sera mara] can be transferred into the loi ana and thus transmitted to God through prayer. Maromak also gave the people the aitos [a carved post with a tip shaped like a human head], which we continue to 'plant'. The aitos represents the early link with God and His domain in the sky; the aitos connected the earth and sky. ${ }^{12}$ Only earlier we did not refer to God as Maromak, but as Lelo Hine, Lelo Mane.

\section{Dispersal from Lemia and the Emergence of the Atsabe Chiefdoms}

The oral histories, which are rather Atsabe centric, suggest that the first settlement to branch off from Lemia centre and become an independent chiefdom was Laclo, ${ }^{13}$ followed by Tiar Lelo and Atu Dame, and finally Boboe. Laclo distinguishes itself in that it faithfully adheres to Kemak traditions and the performance of all rituals in the ritual cycle, even the ones that appear to have disappeared from most of the 13 villages (victims of the Catholic Church's

12 I recorded two main explanations for the significance of aitos. One explanation - the secret meaning of the post - was told only in hushed tones by the sacred men of the village. The other explanation is the most public form, which connects the aitos to the Christian God. According to this explanation, God (Maromak) came down from heaven to look at the first human beings (including ancestors of the Kemak) and divide land among them. The aitos represents His walking staff (rota) on which He rested against a stone. Aitos in its secret (and indeed sacred) meaning represents the founding ancestor (or first ancestor born of the union of Lelo Hine and Lelo Mane), therefore the top of the post is carved with the representation of a human head. The aitos must be made of a special wood from the ai dagha tree. A small menaka (stone platform) and the accompanying aitos must be present at all source houses not just the uma luli. The aitos of all source houses represents the founder of that house. Also according to these more secretive meanings attributed to the aitos, the post carved to resemble a human head must be embedded in a stone platform since the first ancestors arose from the earth and stones, from earthly caverns. Before the uma luli (or other source houses) is built, the axes and swords ( $t$ a no suri) that will be used in acquiring wood from the forest are placed at the feet of the aitos for blessing so that the implements will cut only the wood and not the hands or cause other injuries to the men. Aitos is also said to represent Lelo Hine Lelo Mane and Rae Hine Rae Mane (female earth male earth), and this united divinity is present in the aitos. When the ai dagha tree is acquired for the aitos, the eldest member of the uma luli will assume the role of Lelo Mane, who will call to the spirit of this tree to follow the ceremonial procession that is transporting the tree into the village, and to make the wood less heavy and easier to lift and carry. The elder representing Lelo Mane must lead the procession. The spirit within the aid dagha tree is that of Rae Hine and the aitos is the united presence of sky and earth as they united in primordial times (I was asked not to mention this meaning to the priest or others who might accuse the storytellers of being pagans). 13 As pointed out earlier, Atsabe people recognise that people of Marobo left Lemia first while all other people who were to found the various constituent chiefdoms of Atsabe domain still lived together in Lemia. Given the local perceptions that the Marobo are not as intimately interconnected with the various houses and former chiefdoms of Atsabe as those who make up the Atsabe domain, in oral histories the Marobo rarely if ever get a mention. It is through direct questioning about how the Marobo 'fit' with the rest of the Kemak that one is told that they were the ones to differentiate first from the ancient foundation site of Lemia and that Obulo arose as a settlement through the differentiation of source houses from Marobo. 
interference). Laclo's closest marriage ties are with Boboe, Lemia (Lemia Leten and Lemia Craic) and Tiar Lelo, specifically with the branch houses from the origin village of Lemia. ${ }^{14}$

The foundation narratives of Tiar Lelo village and chiefdom - the second to differentiate from Lemia - are interesting and not just from the perspective that they make copious references to places in the local landscape, including Darlau Mountain. In one version it is made clear that the territory under question belongs to the Lemia founders. This version also places the Boboe and Tiar Lelo chiefdoms in an elder/younger sibling relationship; Boboe is senior to Tiar Lelo based on their founders and the level of seniority of their origin houses in the origin village of Lemia. The narrative also asserts a common origin for Tiar Lelo and Boboe. The story also recognises a hierarchical relationship between the two groups. This, however, is explained from the perspective of the current state of affairs, which takes the political hierarchies within Atsabe domain as a reference point for the hierarchical relation between Tiar Lelo and Boboe.

\section{Version 1: The founding of Tiar Lelo (Ciar Lelo) village}

There were two founding ancestors; they were brothers. The elder founded Boboe, and the younger founded Tiar Lelo. As the two brothers were descending from the top of Darlau Mountain after obtaining fire there, the younger asked the elder: 'What is that place?', pointing. The elder answered: 'That is Ai Rei.' Then the younger pointed to another place and asked again. The elder answered: 'Lesu Mau.' Next the younger cut a hulo bamboo and sharpened the tip into a spear and he threw it towards the sun. The elder chewed on betel and spat far away [lota $a b a$ ]. They did not know where the spear and the spittle landed. They kept descending the mountain and looked for where the spear and spittle had landed. When they arrived at a place that was level and was wet with spittle they named the place Aba Rema [aba: saliva, spittle; rema: level]. This name now designates the territorial domain of Tiar Lelo. When they got to the place where the bamboo spear was standing in the ground on the level surface, the spot was called Hulo Rema [hulo: bamboo type; rema: level]. That is the place where the village was built, the village of Tiar Lelo. Darlau Mountain belongs to the people of Lemia; it was their origin village that was on the top of Darlau. The name of the village Tiar Lelo comes from the act of throwing the bamboo spear towards the sun [tiar or ciar: to throw far away; lelo: sun].

14 Lemia Leten (upper Lemia) is considered the origin village, while Lemia Craic (lower Lemia) represents the expansion of the named houses and branch houses into a new settlement, which currently is located in the Ainaro administrative district. 
The original Tiar Lelo village was established in the place of Aba Rema. ${ }^{15}$ The first origin house was Uma Lulu Ubu within the territory of Lemia Leten. The two ancestors who founded Tiar Lelo were Aba Rema and Hulo Rema. Both ancestors spat betel spittle. Where Hulo Rema's spittle landed became the territory of Tiar Lelo. Where Aba Rema's spittle fell became the Kumubia River in Lemia. Uma Mali Ubu in Lemia was the origin house of the ancestral brothers.

\section{Version 2: The foundation of Tiar Lelo as a chiefdom}

At first there was only one domain and Laclo was a part of this domain but was a separate chiefdom that descended from Lemia. The one domain was Lemia, the place of true origin of all Kemak on Darlau Mountain. Tiar Lelo split off first (and then Boboe split off from Tiar Lelo). The Boboe people, the Tiar Lelo people and the Lemia people are descendants of three founding brothers: Lemia and Laclo people from the eldest brother, Boboe people from the second brother, and Tiar Lelo people from the youngest brother. The split of Tiar Lelo from Lemia occurred over an insult and ensuing warfare over it. The story of how the split occurred is as follows: an elder named Sur Talo was the dato of the Tiar Lelo settlement within the domain of Lemia. He was also a relative of the senior house of Lemia. One day when Sur Talo was taking off his sword, the tip accidentally pointed towards the son of the ruler of Lemia. This was perceived as a grave affront and Sur Talo was put to death. This precipitated warfare between Tiar Lelo and Lemia and brought about the establishment of Tiar Lelo as a separate chiefdom.

Another version comes from the family of the koronel bote or liurai family who controlled the Atsabe domain from Tiar Lelo at its centre. This alternative version of the foundation narrative attempts to incorporate the line of the outsider/usurper of power - namely, the line of the koronel bote-as it attempts to justify the presence of Uma Kase ('the house of the foreigner/outsider') as part of the Tiar Lelo social structure. Through the narrative, the myth's tellers seek to legitimise the authority of the group that will unite the various related chiefdoms that derived from Lemia on Darlau into the Atsabe domain. Also, while other narratives I will discuss below emphasise that Tiar Lelo separates first in terms of establishing its own settlement and chiefdom, and only thereafter does Boboe achieve its own independent status, this origin story clearly suggests

15 'When the last koronel bote opened up rice fields there, they were all washed away by landslides - the lesson was that agricultural fields must not be opened on a sacred site. The last koronel bote is descendant from Koko Lia who was an outsider and conquered all the people originating from Lemia.' This was part of the original telling of the variant of foundation. It is included here as a convenience, so it does not disrupt the flow. 
that when Tiar Lelo was first established, the distinction in terms of separate chiefdoms was not yet present. According to this version, two origin houses of Lemia branched out to establish their settlement in Tiar Lelo. The claimed seniority of Tiar Lelo over Boboe is a legitimisation device employed by the myth's tellers who are descendants of the invaders and outsiders who became integrated into the social structure of the original Tiar Lelo group and who, in effect, usurped the authority of the original Kemak settlers of Tiar Lelo.

\section{The Story of Conquest (Recounted by descendants of the koronel bote who claim direct descent from Koko Lio)}

Koko Lio first lived in Ainaro, Hatubuilico. Next he went travelling and his journey took him across Ramelau. He decided to settle in Genu Mera in the Lemia domain/chiefdom ${ }^{16}$ where he left behind his authority in the form of the first Acu Boso [a stone platform called menaka by all other groups of Atsabe, except those in Tiar Lelo] and Aitos. ${ }^{17}$ These served not only as a sign that he once settled there but also that he had the authority over the place and he was the ruler. He possessed a sacred tablet, the size of a cassette, ${ }^{18}$ which he could order to make a loud sound that would gather all the people together. When the people came to see what the noise was, he announced to them that he was the ruler and he had authority over the place. Next he travelled to Soru Aci in Laclo. The ruler there bowed to Koko Lia and submitted to his authority, and that domain was also integrated into the growing domain of Koko Lia. The various chiefs submitted to Koko Lia and were integrated into his domain, because he possessed three luli (sacred) objects: the tablet, a rattan staff that could change into a snake and a special weapon - a gun from which lightning emitted. He could also travel with superhuman speed and glowed like the sun. After Soru Aci, Koko Lia went to Ai Lea (now a town of Atsabe in the centre of the subdistrict); then he continued to travel back up to Darlau Mountain and also brought the ruler of Lemia into submission. The ruler was Lei Mia. When Lei Mia and Koko Lia were descending from Darlau Mountain, Lei Mia spat betel spittle upwards and it landed close by the Kumubia River [a river in the territory of the present-day Lemia Leten people]. ${ }^{19}$ When Koko Lia spat, his betel spittle landed very far away - at Abu Rema. There is a spring there called Lias Tete, which originated from his spittle. The

16 The storytellers used the Indonesian term kerajaan (domain).

17 In Tiar Lelo, the origin houses are also not round architecturally but rectangular.

18 This was an interesting comparison with a modern object, especially since I was using a digital recorder and not a tape recorder.

19 In the myths of all other people of Atsabe, this story is told as the founding ancestor whose origins are in Lemia on Darlau. Koko Lia's story is narrated much later in the accounts of oral history when his conquering of the Atsabe people is emphasised. 
ruler of that region, the ruler of Lias Tete (Tiar Lelo), also submitted to the authority of Koko Lia, at Atsabelau Mountain. The ruler of Lias Tete was Loko Ubu. So, the entire domain of the Atsabe was built by Koko Lia as all the local chiefs and rulers submitted to his authority and sacred power. Koko Lia's domain and authority extended over a wide territory, with borders to Atabae, Bobonaro, Hatubuilico and Aileu at Orna Mau Siga. One of his wives came from Atabae, and Koko Lia gave his umamane [wife-giving house] the right to govern Atabae. The domain of Atsabe remained the same until the time of Dom Siprianu [a ruler of Atsabe] prior to the Japanese invasion. Dom Siprianu then extended the territory of the Atsabe domain into Suai. Koko Lia sent his younger brother to acquire and govern the territory of West Timor. His brother was called Nai Loko and he was to govern the Wehali domain, but the people there did not accept him and rebelled against his rule. He returned to report this to his brother, Koko Lia, in Atsabe. So, Koko Lia sent his youngest brother, Nai Saur, who became ruler of Wehali. Koko Lia possessed sacred power so strong that all his wives were killed by it. Only the wife he took from Uma Kai Si Ubu in Obulo survived because before he took her as wife, he transferred his sacred power into a gong [ko]. This gong is now a sacred heirloom protected by the uma luli. Koko Lia's staff and tablet - the other sacred objects - were taken by Mortago, a Portuguese stationed in Hatolia, to the museum in Lisbon. The gong will sound by itself as a warning and omen that a member of the house will die.

\section{The Sacred History of Atsabe ${ }^{20}$}

This origin story attempts a grand synthesis of the historical experiences of the Kemak people from primeval times, Timor's relations with other islands, relations among the different groups within Timor from the time of the first founding human ancestors, and the hierarchical nature of relations among Kemak groups. A version of the myth below demonstrates the significance of place and local geographic features in the formulations of group identity as well as in narrating complex histories of human migration and group relations. From the Kemak perspective, Ramelau Mountain is considered the place of origin of all Timorese people. This is consistent with the Atsabe Kemak conception that

\footnotetext{
20 I recorded variants of this origin narrative from Boboe, Laclo, Lemia and Obulo. There was a defiant and challenging tone to the introduction of this narrative by all the 'sacred men' - challenging the authority of Tiar Lelo, or rather, the authority of the line of the king of Atsabe. Some of these Kemak consultants also revealed that the long 'historical' narrative could be pictorially represented and that particular sacred parts of the story are often drawn while recounted in a very low (almost mumbled) voice. Curiously, the pictographs resembled motifs of tattoos, textiles and even some of the carvings on uma luli. When I mentioned the resemblance to tattoos, one of the elders recounting the narrative pulled up his sleeve with a gentle smile to reveal a tattoo that looked like the drawing he had just made while explaining the pictographs.
} 
considers it the current place for the villages of ancestors. This myth also gives an example of Kemak topogeny (cf. Fox 1997), which establishes discursive links between groups of people and localities through the recitation of a sequence of place names (see also Reuter 2006a:19).

The earliest ancestors emerged from the earth. The very first ones were Loa Lae and Mau Lae. They emerged but continued to live deep within the earth, lime and earthen cave. The first ancestors were giants. When they emerged from the earth, they emerged with a white textile [taisbuci] that was so long that when the ancestor took it up to the Ramelau Mountain it covered the mountain's slope. Bu Leki was the wife of Loa Lae Mau Lae. They have rights over all of Timor; his and her descendants have rights to all of Timor. They had two children: Suri Mola and As Mola. Their founding house was called Acula Mundu. Their descendants spread to populate Ambon, Alor, Kisar and also Flores. These early ancestors were living on Ramelau Mountain. They were digging for salt. Then a flood [tasi beno] came, the sea covered the land right up to the Ramelau Mountain. So they had to build their homes on the top of Ramelau. When the sea receded there were no more trees left on the lower lands, everything was swept clean. Land was still very small at that time. So the ancestors came down from the top of Ramelau and went to the earth cave of the first giant ancestors (they were still alive after many, many generations). They looked down inside the giant cave of the first ones. They asked for trees and vines to replant the earth. From below they were given a sacred basket [taka luli] filled with 20 vines [tali hua] and fruit trees [ai hua]: five male and female pairs of ai mamar, ai ta buci, ai ora, ai ili goru, ai taha buci [all different local trees] and five male and female pairs of vines: tali si meta, ga tala, tali sogha, tali nena, tali oho gatal bote. Two ancestors, Mau Hui and Loko Hui, made a menaka in Boboe. At that time the land was still very small so they threw fruits and vines [sali tali hua] in different directions and in each direction, the land expanded so the world grew larger.

Four ancestors, Loe Mau, Dada Mau, Pi Kali Mau and Kali Mau, went on a trip [Loe Mau and Dada Mau each founded a source house; Pi kali Mau and Kali Mau together founded one house]. They were heading to Liu Rai Tasi Balu, but only got as far as Lis Tete Bu Rema. It was very dark and they could not see the path. So they went to Loa Lae and Mau Lae to ask for a big male disc [cumara] and used this to light the path [pilo sala]. On the way they went down to the River Luro and then went up 
to Boboe. With their spear [belaki], they made a hole in the earth after stabbing the earth. They looked inside and saw Bu Leki weaving. They threw down a very sweet orange. The giant ancestress was surprised as the orange fell on the tais. She called up to them: 'Speak Mambai' [as an aside, the teller explains, 'the first language of Timor was Mambai']. Then she said: 'Not bad!' ['mika ba kode']. ${ }^{21}$ Then the ancestors pulled up from that earth cave the sacred sword and spear and the sacred axe [belaki luli, suri luli, ta luli]. Then the ancestors went to cut down some sacred trees [ai mamar, ai ta buci, ai ora, ai ili goru and ai taha buci]. There are no more sacred trees inside the earth, in the ancestral earth cave; they are all on top of the earth now. They cut down the trees to build houses but the sacred trees were so heavy, they could not lift them. So they piled the trees on the sacred spears and then they could easily lift them to take back to the village. First they made rectangular houses with no roof. Then they remembered and made long houses [lobor] with rooms for each family. But still they did not build a roof. When the big rains came, they were always wet. They observed that their dog was always dry. So one day they tied the lime container with a piece of cloth to the dog's neck and followed the chalk line. When it rained, the dog hid inside the high grass [lei: Imperata cylindrica] and was dry. So they collected this lei-grass [dut mau lei] and covered their houses. But with heavy rains they still got wet so they went to get a central post and two supporting posts and made a round roof that they thatched with leigrass. Now that is how we make our uma lulik.

When they first wanted to make houses and the village, whenever they cut a tree or dug into the earth, the earth and trees screamed. So the ancestors climbed down into the earth cave of the first giant ancestors and asked what to do. The ancestors gave them a small plaited basket and betel/areca [taka ana with da'a no bo] and prayer beads [loi ana]. The four ancestors made a menaka from four stones and on top of the platform they placed their offering with the sacred beads [loi ana]. After the offering, the earth and the trees did not scream when wounded and it is still like that today.

Next came another great flood [tasi beno] where the sea level rose and flooded the land. The ancestors went to war with the lord of the sea. Lelo Rae ${ }^{22}$ went to war with Kuku Ratu Tasi Ratu. Lelo Rae asked the

\footnotetext{
21 Mika ba kode was translated by the teller as 'the orange is sweet'. I would like to thank the reviewer of this chapter who is knowledgeable in the Mambai language, who pointed out that mika means 'not' and $b a$ kode means 'bad'; thus, a literal translation would be 'not bad'.

22 Lelo Rae, which literally means 'sun earth', is a collective name that subsumes the first original ancestral brothers, Loa Lae and Mau Lae. Thus, taking the literal meaning, the first ancestral brothers represent the sun or sky and the earth, alluding to the union between the sun and earth that produced the first ancestral progeny.
} 
four ancestors to return the sacred swords and spears, and they did that. Lelo Rae chased the lord of the sea with the sacred spear [belaki luli] chased him as far as Ba Tata. Lelo Rae speared Kuku Ratu Tasi Ratu until his tongue hung out. In Boboe Leten, Uma Tali Meta stored the tongue as its sacred heirloom. The name of the spear is Bere Bada Mau Lai; another spear used is called Cima Mo Lako. (Now it is the heirloom of Uma Bere Heu.) So at Ba Tata, the lord of the sea was killed. The spear Liu Rai La Gora was thrown forward and landed by the rivers of Gora Racu and Gora Ai. The lord of the sea started to revive so at these rivers the ancestors cut the lord of the sea into pieces with the sacred sword. He kept hacking with the sword at the lord of the sea but the pieces kept reviving. But his wife, Abo Hine [title of the first ancestress], came to help and with one hack, cut off the head; so the lord of the sea finally died. While the rest of the body was washed out to the sea as finally the sea retreated, the head stayed behind. It was so heavy that it could not be lifted. The head stayed by the rivers and was going to revive if not disposed of and then the sea would return and there would be a flood. So the ancestor called up from inside the earth Manu Napa Tasi and he came. The ancestors (Lelo Rae and the four) told him that the head of the lord of the sea could not be lifted and could Manu Napa Tasi help? What payment should they give? Manu Napa Tasi said no payment was required but in the morning he would come and take chickens, pigs, dogs and goats. So Manu Napa Tasi lifted the head and carried it to Adi, a place on Ramelau. The spears and swords used to kill the lord of the sea lost their edge; they are now dull.

Next the ancestors built a dam from mi kase and ai tasi wood as a boundary for the sea. But this was not strong enough to hold the sea. So they looked for aka diru to reinforce the woods from which the dam was built. So now there are no more aka diru here; all are down on the coast. When the sea rumbles, these vines also make noises like when the winds make the reeds creak.

Next the ancestors went to look for good land and found it in Loes [now in Bobonaro district]. They made their houses in Loes. There were eight straight paths in Loes that led to the houses. The founding house in Loes was Uma Acu La Mundu. Houses were made like large granaries [lako bote]. Loes was a very wealthy region, everything was in plenty: animals and wealth inside the house. The ancestors Laku Mau Mese Mau went to look for Krisi Mau Talo Mau of the house Acu La Mundu and asked him to look for the feet of the lord of the sea so that the sea would not rise again and the lord of the sea would not revive. They searched for 
seven years; on the coast they finally found the feet and speared them with the sacred spears and twisted the spears in a counterclockwise direction so that the feet ran back to the sea.

By the time they returned to Loes, they found that all the animals and sacred cumara [cumara mia] were divided among the people of TimorLoro Sa'e, Alas, Betanu, Tutuala, Kupang, Liquiça and Maubara. The four ancestors (Loe Mau, Dada Mau, Pi Kali Mau and Kali Mau) were disappointed that in Loes they did not wait for them and they divided everything already.

The ancestors were called Kole Bau and Mau Bau. Their sons were called Rai Sa and Kelo Hale, respectively. Kole Bau Mau Bau gave the four ancestors a huge boulder called usi luli to place on top of the menaka in order to repair it and strengthen it since the sea had eroded (damaged) it.

Next they made a multicoloured sacred mortar [nesu luli]. They also raised eight wooden posts that they brought from Loes. These posts were for hanging the meat of sacrificial animals [ri pun: 'source posts']. Mau Bau was the elder brother and Kole Bau was the younger brother. They brought a large earthenware water jug with a narrow neck [cu'u bot]. ${ }^{23}$ The two ancestors took the water jug and the sacred mortar to get seawater. Kole Bau told Mau Bau to get inside the nesu luli, and then dipped it into the sea. Then Kole Bau got inside the $c u^{\prime} u$ bote and he also dipped his jug into the sea. These containers were then taken to the village. As they sat inside the containers, the people gathered around the eight posts with meat hanging from them. ${ }^{24}$ At night the four ancestors called the dog and the dog accidentally knocked over the containers, which broke into pieces and the seawater ran out. As the seawater returned to the sea, it washed some people away while others ran and escaped. Seven ancestors ran to Ai Ede (near Lemia) - a place of origin of the ancestors of Atsabe Kemak. The first ancestor, Loa Lae Mau Lae, also died at Ramelau and is buried there. The children of this giant first ancestor are Me Tasu and Bole Asu.

Others who escaped the seawater are the ones who populated Timor Loro Sa'e. The path they followed is as follows: to Maubara, Liquiça, Curi Leu, Rae Pu, Tibar, Bila Verde, Be Ai Kua. In Bila Verde they found an egg and took it with them. The place where this egg hatched they named Manututu. The ancestors, whose chicken that was, were called

23 Vessels of this kind are still used in Marobo.

24 After ritual sacrifice, the meat of the sacrificial animal is first hung on posts after the butchering process, ready to be cooked for a communal feast or divided among the participants. This passage seems to allude to some ritual undertaking in the village. 
Me Tasu and Bole Tasu. They gave the name to the land of Manututu at La Lia, where the egg hatched. As they went on, the place where the chick made a sweet sound they named Be Masi. The ancestors had many children and their descendants now populate the eastern part of East Timor.

Those ancestors who were washed out to sea became the ancestors of other people, but they are all descendants from Timor. Two ancestors whose names are not known were washed away by the sea as far as Angola. Their father was from Loes. One day when this ancestor was sitting in the morning, his tais slipped down so his butt was showing. His children saw this and were laughing at him. So the father said to them 'one day when you have children their skin will be black and their hair will be crinkly'. So that is why the Angolan Timorese are black with crinkly hair.

Other ancestors who were washed out by the sea landed on West Timor, Alor, Flores, Kisar and Ambon. These people are descendants of Flores. When the first giant ancestor was dying, he divided the languages as well. His language was Mambai, the first language of Timor; he divided Kemak, Makassai, Tetun, Galoli, Bunaq-all the languages of Timor Island, even those of West Timor.

\section{Oral History Legitimising Power Relations}

It is interesting to note some of the differences in emphasis between the two previous narratives. In the version of the foundation of Atsabe that was told by family members of the Atsabe ruler, the emphasis was placed on the hierarchical power relations both within and outside the domain. The myth extended to a discussion of Atsabe's perceived circle of power, even claiming conquest of the influential domain of Wehali and the installation of a ruler there who derived from the family of the Atsabe ruler. Therefore, the myth also aimed at explaining the basis of the power relations between Atsabe and other domains of the western region of Timor-Leste and the eastern part of present-day Indonesian Timor. The sacred history of Atsabe, on the other hand, stressed cooperation and emphasised relations of connectedness among the various groups of Timor including groups outside Timor with virtually no emphasis on power inequalities. Other striking differences between the two myths are the different ways of alluding to legitimacy - namely, utilising the sky in place of the earth metaphor for legitimacy. In the first myth told by the descendants of the Atsabe ruler and ultimately by descendants of an outsider conqueror, power and legitimacy derive through an association with the sky. In the second myth, on the other hand, legitimacy derives from the sacred connection with 
the earth. In Kemak conceptualisations of the dual pair of sky and earth, the sky is the superior category to that of the earth. This categorical superiority of the sky is not, however, an uncontested notion, particularly by Kemak ritual leaders (the 'sacred men' of the group) ${ }^{25}$ who derive from Lemia and not from the line of the rulers of the Atsabe domain. Without exception, in my interviews with the 'sacred' men and ritual leaders of groups that derive from Lemia, there was a strong objection to and even criticism of the Tiar Lelo version. They claimed that even the telling of Kemak origin narratives was changed by the Atsabe ruler/conqueror line in giving priority to the sky and to Lelo Hine and Lelo Mane over the 'real' origins of all Kemak human beings - the ancient human ancestors who emerged from the earth and the first sacred giant ancestors who lived in the caves in the bowels of the earth whom the Kemak venerated, and from whom they learned and derived all things of human need. These 'sacred' men and ritual leaders also emphasised that the version of the origin myth that gives superiority to the sky and a sky god was strengthened after Catholicism was established. The family of the Atsabe ruler was indeed a strong supporter of the Church and of the spread of Catholicism and some of their claims to power were indeed strengthened by the Catholic Church.

While there were some variations as each of the four main groups tried to stress their own importance or 'priority' or 'seniority' in terms of justifying rights to power and authority, there was general agreement that the place of origin for all Kemak was Lemia on Darlau. Here the first Kemak ancestors occupied the sacred mountain slope where the sky and earth were connected by a vine and from where fire originated. As to how Tiar Lelo became the ultimate authority over the Atsabe Domain, there are various versions.

According to oral histories, the establishment of settlements that later expanded and had autonomous authority over their territorial domains (talked of mainly in terms of founder-house names) is viewed as the first branch of satellites from the Lemia domain. There is much emphasis on the story of the establishment of Tiar Lelo and Boboe's settlement. Laclo has its own stories of the foundation of its settlements and territory, which its population insists occurred before that of Tiar Lelo or Boboe. At least one informant pointed out that Obulo's foundation (like Marobo's) is contemporaneous with Laclo's in the mythical chronology. Chronologically, the establishment of Atu Dame (Malabe) is closely linked with that of Tiar Lelo. While these branched settlements grew into independent

25 See Molnar (2006) for a fuller discussion of the notion of 'luli' and the secular and ritual personages that are imbued with spiritual potency that makes them 'sacred'. Here I would only note that a ritual leader (gase $u b u$ ) of a group derives his power and legitimacy through descent from founders and through ritual knowledge, particularly through his role as the guardian of sacred history and lore. His domain of authority is in the ritual realm. 
chiefdoms, all acknowledged the overarching sacred authority of Lemia. These small chiefdoms were, however, autonomous in terms of political power and territory.

The various claims made by these origin myths are interesting in terms of current relationships between the groups and especially in terms of the use of varied sources to claim legitimacy for power and authority, as often these claims hark back to the oral histories. There are elaborate versions of how Tiar Lelo became the dominant political authority in the region and united the politically and territorially autonomous smaller chiefdoms that derived from Lemia into the Atsabe domain. This unification was accomplished by a supernatural ancestor from the sky, Koko Lia. He first conquered Laclo, then Ai Mea, which was a hamlet of Tiar Lelo and thus part of the original Tiar Lelo people's settlement. Next Lemia was conquered and then the ruler, Loko Ubu of Lias Tete, a settlement within the territory of Atu Dame. Then the conquest continued and spread out to Obulo as well as Atabae. The conquering ancestor intermarried with the main house of Tiar Lelo and also established marriages with the main source houses of each of the conquered chiefdoms. Lemia and Obulo were acknowledged as major chiefdoms that had authority over matters within the territory of their own chiefdoms and were essentially in a tributary relationship with Tiar Lelo. On the other hand, the Laclo and Atu Dame chiefdoms were completely swallowed and incorporated into Tiar Lelo and were completely under its authority. Thus, Laclo and Atu Dame had no autonomy and they were integrated into the Tiar Lelo chiefdom, which was the centre of authority for the whole Atsabe domain. The Atsabe domain was established via expansionist conquest.

Tiar Lelo of Atsabe domain then reigned unchallenged and it was not until a serious uprising in the former Atsabe domain, which the Portuguese tried to quell, that Boboe split and founded its own chiefdom. This split was in response to the fact that most of the Boboe group was almost wiped out during the uprising. Boboe was, however, still part of the larger Atsabe domain with the same status as Lemia and Obulo chiefdoms within the larger Atsabe domain. The various oral histories describe the situation as a large ruler having dominion over smaller chiefdoms. The ultimate authority resided within the Atsabe ruler with its leadership coming from the Tiar Lelo group. Lemia's authority as the place of origin encompassed that of Obulo, Laclo and Lias Tete (Atu Dame) as these chiefdoms derived from Darlau Mountain as well. Tiar Lelo and Boboe were just settlements within Lemia chiefdom's domain.

The nature of the relationship between chiefdoms within the former Atsabe ruler can be summarised as follows.

- The Tiar Lelo chiefdom had the highest political authority as the centre of power of the entire Atsabe ruler and as such had precedence over Lemia, 
Obulo and Boboe. The koronel bote, the ruler, to whom all other chiefs were subordinate, was based in Tiar Lelo. Atu Dame was considered a part of both Tiar Lelo and Boboe. Thus, in the political hierarchy, Tiar Lelo chiefdom had superiority - the place where an outsider had gained control of local power and established itself through marriage within the most senior house of Tiar Lelo.

- Relations with the origin place of the Kemak, the Lemia chiefdom, were described in marriage terms: Lemia is wife-taker to Tiar Lelo (nai hine nai mane).

- Relations with Obulo were also described in marriage terms: Obulo (and Marobo) are wife-givers to Tiar Lelo.

- The Obulo chiefdom appears peripheral in most Atsabe accounts, but always had excellent and close relations with the former chiefdom of Boboe. The relationship is described as that of mutual alliance, friendship and defence

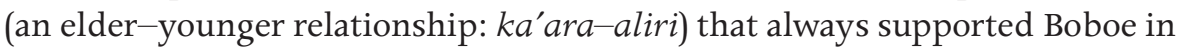
any dispute or war. It is interesting to note that Obulo has some source houses that are wife-givers to Tiar Lelo and specifically to the house of the koronel bote and its junior-branch named houses, the group with which Boboe has had the most disputes and conflict. The Obulo chiefdom, while considered a part of the Atsabe ruler, is nevertheless viewed as a part of Marobo, and the Obulo people are considered Marobo (a fact inconsistent with the Marobo chiefdom granting independent chiefdom status to Obulo).

- Relations with Boboe Craic ${ }^{26}$ were described as a friendship alliance, ka'araaliri relationship, with Boboe Leten as a marriage ally: Boboe Leten is wifegiver to the main source houses of Tiar Lelo.

- Atu Dame's closest relations are with Boboe (as a former chiefdom) given that their connection is described as an elder sibling/younger sibling relationship. Atu Dame and Boboe are descendants of the same ancestor but Atu Dame are from the first wife of the ancestor and Boboe are from the second wife of the ancestor. This is also reflected in the very close marriage-alliance ties that exist between the two villages and also in the fact that Boboe has some of its branch houses located in Atu Dame. According to the oral narratives about the first ancestral pair to leave Lemia, Tiar Lelo is the descendant of the younger brother and Boboe of the elder brother.

\footnotetext{
26 Boboe Craic as a settlement/chiefdom is within the territorial domain of the former Boboe chiefdom. This settlement is, however, considered to be the most recent, established only after the Manufahi war, with a foreigner (a Manututo man) marrying a woman from Boboe chiefdom and thus founding Boboe Craic. The descendants of Boboe Craic are viewed as outsiders, not 'true Kemak'. Therefore, the nature of the relationship with Boboe Craic is not conceptualised in terms of the complex dynamic networks of marital alliances but simply in terms of an ally.
} 


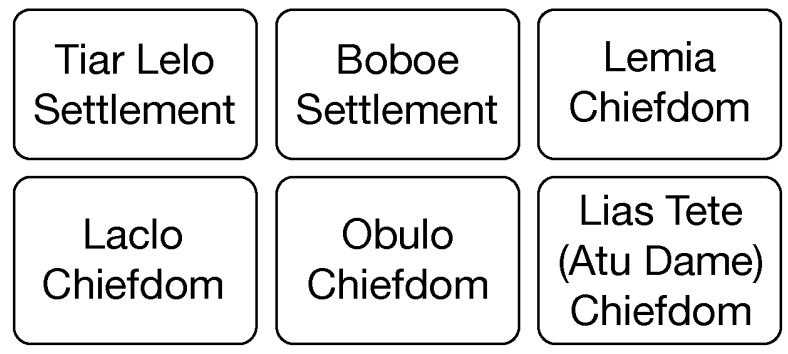

Figure 5.1 Diagrammatic representation of authority over domains prior to the establishment of the Atsabe ruler

In Figure 5.1, the chiefdoms are independent of each other in terms of authority over their respective domains. Boboe and Tiar Lelo are satellite settlements from Lemia and not yet at chiefdom status.

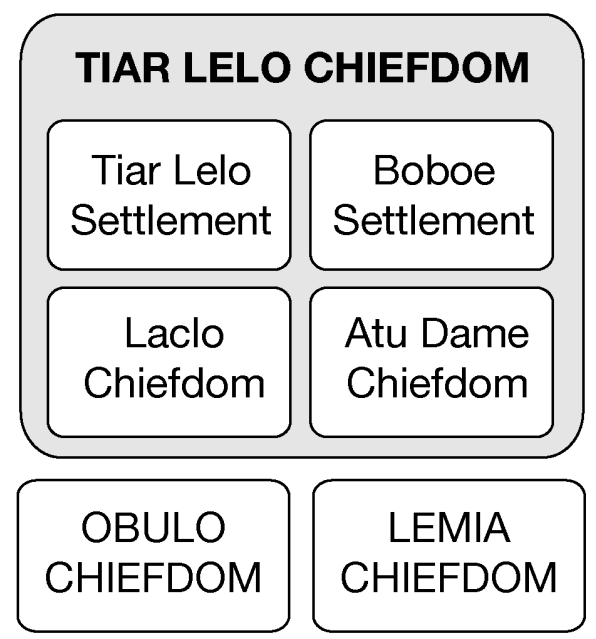

Figure 5.2 Diagrammatic representation of authority over domains with the centralisation of authority by Tiar Lelo chiefdom vis-a-vis the outsider conqueror 'installing himself within'

Figure 5.2 represents the distribution of authority after the conquest and unification of the chiefdoms by an outsider. Tiar Lelo settlement, where the conqueror installed himself through marriage, became the centre of authority for the Tiar Lelo chiefdom after Boboe settlement, Laclo and Obulo chiefdoms were conquered and integrated into the sphere of authority of Tiar Lelo. Laclo and Atu Dame become sub-chiefdoms under the authority of Tiar Lelo. Lemia and Obulo retained their autonomy within their respective domains through a tributary relationship with Tiar Lelo chiefdom. 


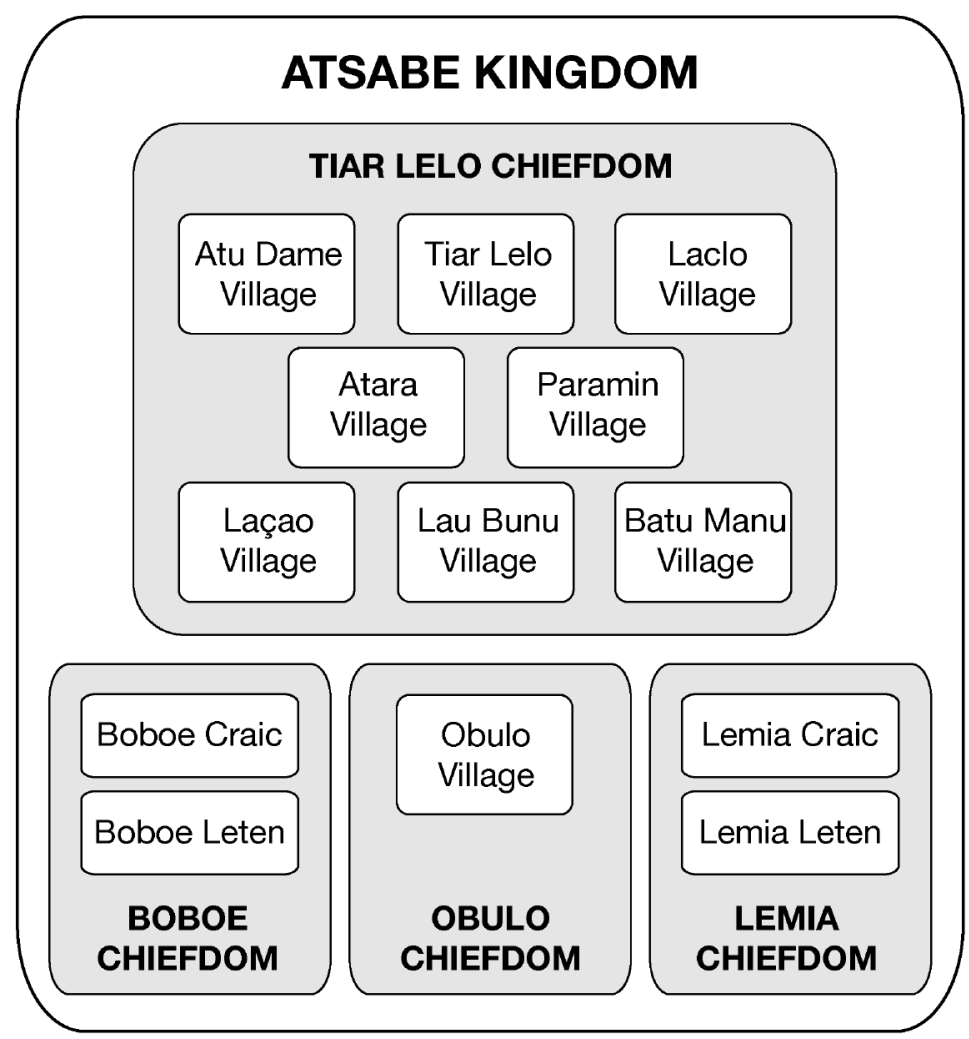

Figure 5.3 Diagrammatic representation of authority and territorial domain of the Atsabe ruler

Figure 5.3 illustrates how at the height of the Atsabe ruler, Atu Dame and Laclo no longer had chiefdom status but were village settlements within the Tiar Lelo chiefdom. As the figure shows, several other villages arose through group differentiation. Boboe attained its chiefdom status and, along with Obulo and Lemia chiefdoms, possessed semi-autonomy over its own domain.

\section{Rulers, Chiefs and Village Heads}

Political leadership of the various levels of territorial domains in the former ruler of Atsabe resided with the koronel bote, nai, dato and rati. The Atsabe ruler was referred to as the koronel bote. The heads of former chiefdoms (chiefs) were called the dato. The chiefs of the chiefdoms of Obulo and Lemia, however, had the title of nai, which is higher in status than that of dato. This higher status reflected the seniority and autonomy of their chiefdoms compared with that of other chiefdoms. While both Laclo and Atu Dame were incorporated into the Tiar Lelo chiefdom and both lost their autonomy, the leaders of these 
former chiefdoms were nevertheless called dato. The heads of villages enjoyed the title of rati. In terms of hierarchy of authority, the nai, dato and rai were answerable to the koronel bote. The nai and dato, however, did appear to enjoy a certain degree of autonomy and had authority to deal with the affairs of their chiefdoms, particularly when settling internal disputes and matters of inheritance and land issues. They also had authority to organise the inhabitants of their chiefdom for common undertakings, whether this involved communal work or ritual undertakings. The rati enjoyed similar autonomy when dealing with the internal affairs of their own village. Prior to Portuguese colonial presence in Atsabe, the domain was governed by the koronel bote in consultation with a council of elders (bei), which comprised the chiefs and village heads. Informants likened this council (bei) to a parliament. In addition, the koronel bote appointed a war leader, eru ubu ahi nipa. ${ }^{27}$ This was necessary since there were many wars in the past with other groups and indeed many uprisings against the Portuguese. The war leader and the warriors came from Uma Mane Itu, an origin house in the Tiar Lelo group that was a wife-taker of the house of Lulu Ubu (founding house of the Tiar Lelo group). During the time of war, the war leader's authority superseded all other authority (except that of the koronel bote to whom the war leader was directly answerable). Uma Mane Itu remains to this day the 'hereditary army' of the descendants of the koronel bote's family.

\section{Conclusion}

The Atsabe Kemak, like other Austronesians, have a preoccupation with origins. The origin stories discussed in this chapter provide the Atsabe Kemak with sources of authority when asserting their legitimacy and rightful place in hierarchical social relations within the former Atsabe domain. They are also invoked when challenging such hierarchies as people and groups negotiate their power and rights to authority. These origin stories of the past provide the Atsabe Kemak with the precedent and patterns for ordering their current social relations (cf. Fox 1996a:5, 2000:1-29). As Fox (1996a:5) points out, 'indigenous ideas of origin involve a complex array of notions. Conceptions of ancestry are invariably important but rarely is ancestry alone a sufficient and exclusive criterion for defining origins. Recourse to the notion of place is also critical in identifying persons and groups, and thus in tracing origins.'

Atsabe Kemak stories have shown that place is a significant metaphor for discourse on history, social relations in terms of inter and intra-group relations of precedence, on the organisation of the former Atsabe domain, and on

27 Eru means 'monkey', ubu is 'lord' or 'owner', ahi refers to 'pig' and nipa means 'teeth'. Thus, the expression literally means the monkey lord and owner of pigs' teeth. 
legitimising the authority - and the sphere of influence of this authority - of the Atsabe ruling house. There is a great emphasis on the founding village, the founding ancestor and the ordering of houses and social relationships in terms of both place and ancestor. As Clamagirand (1980:140) points out - and this is also true for the Atsabe Kemak - there is no Kemak term used for village. Settlements are, however, named after their location in relation to the land and often in association with a particular action taken by a founding ancestor. Aba Rema, for example, was named for the plain where mythical ancestral spittle landed. McWilliam (1997:106) also draws attention to the importance among the Meto of West Timor of 'associating the group's name with specific places and named localities', thus affiliation extends spatially across the landscape.

For the Atsabe Kemak place, origin villages and named houses are basic structuring units. The name of the settlement is generally used to talk about a group, although the first house's name (the house of the founder ancestor) may also be used in a similar manner. Often this core source house encompasses the other main source houses that, in turn, have other named house branches. Usually the first main house is the uma luli (sacred house). Named houses are the basic units of marriage exchange and thus the basic anchor of a highly complex nexus of alliances. There are many named houses but people tend to cite the main source houses in the first instance since all other named houses derive from these main source houses (cf. Clamagirand 1980).

Indigenous authority (in ritual, land and governance matters) is conceptualised as the main right of Lemia, the founding settlement and the origin of all Kemak people. ${ }^{28}$ The Kemak explain this right with reference to a number of key factors-namely

- with reference to the origin stories

- with reference to Darlau being a sacred mountain where earth and sky were joined and ancient ancestors had immediate relations with god and ancestors

- this connection with the sacred place imbued the people of the founding settlement of Lemia with 'sacred power/spiritual potency' (luli)

- Lemia people gave rise to all other Kemak through the dispersal of the population via the branching of the key source houses and the subsequent complex, interwoven affinal relations between core source houses and subsidiary named house branches.

The authority of Tiar Lelo is intimately tied up with the power of outsiders who subjugated the local population through conquest and then intermarried

28 I have mentioned in passing the issue of challenging local hierarchies and rights to power within the former domain of Atsabe. These are more complex matters that I will have to address in another venue. Here I only wish to point out the basic principles and reasoning provided by the Kemak Atsabe for understanding the founders' struggle for authority. 
with emplaced source houses (see McWilliam, this volume). Their power is conceptualised mainly in terms of political governance and is grudgingly accepted. In local discourse, Tiar Lelo and the line of the koronel bote (the descendant of the outsider conqueror Koko Lio) are intimately connected to other sources of external power over the Kemak, including that of the Portuguese, the Catholic Church, the former Indonesian Government, and even the current national government. ${ }^{29}$ Authority in these terms is conceptually linked with the power of coercive force and that of outsiders. Given this way of thinking, the legitimacy of this form of authority and the groups linked with it has always been contested, challenged and questioned in Atsabe.

Every Atsabe group - aside from Tiar Lelo - vehemently denies the legitimacy of Tiar Lelo when discussing the political history of the Atsabe domain. In these discussions, the concept of luli was consistently raised, as were Atsabe conceptions about the degree and amount of sacred power that groups and people possess, particularly in relation to sources of $l u l i^{30}$ and their personal connections with ancient ancestors, founders, Lemia and other sacred places and objects. Framing these distinctions in terms of earth and sky received consistent attention. Koko Lia's luli is legitimised through the claimed connection to the sky through the origin myths. Given that the objects that were imbued with this sacred power are, however, no longer in Tiar Lelo's possession, in popular discourse this opens the possibility for questioning the legitimacy of the ruling family (and Tiar Lelo) while the sacred power emanating from Lemia and its rightful descendants is re-emphasised. ${ }^{31}$ Darlau continues to have a prominent presence in the lives and social relationships of the Atsabe Kemak. It is not just a real topographic place but serves as a metaphorical nexus for a wide range of Atsabe Kemak conceptions of origins and inter and intra-group relations.

\section{References}

Barnes, R. H. 1985, 'Tanebar-Evav and Ema: variation within the eastern Indonesian field of study', Journal of the Anthropological Society of Oxford, vol. 16, pp. 162-71.

29 From the former ruling family of Atsabe, a number of people received government jobs, whether as subdistrict administrators, members of the new East Timorese police force or parliamentary representatives for one of the political parties.

30 For further discussion on 'luli', see Molnar $(2005,2006,2009)$.

31 In Molnar (2004), I discuss the religious aspect of the Kolimau 2000 movement, which harked back to these indigenous notions of 'sacred potency', and Lemia on Darlau featured prominently in Kolimau presence in Atsabe. As a millenarian movement, it possessed features that questioned the rights and authority of both the Catholic Church and the new national government (the two being viewed as political bedfellows intimately linked with outsiders). 
Clamagirand, B. 1971, 'Rapport de Mission au Timor Portugais', Asie du Sud-Est \& Monde Indonesien, vol. 2, no. 2, pp. 22-9.

Clamagirand, B. 1972, 'Le Travail Du Cotton Les Ema De Timor Portugais', Etudes interdisciplinaires sur le monde insulindien. Archipel 3, vol. 3, pp. 55-80.

Clamagirand, B. 1975, 'La Maison Ema (Timor Portugais)', Asie du Sud-est Monde Insulindien, vol. 6, pp. 35-60.

Clamagirand, B. 1980, 'The Social organization of the Ema of Timor', in J. J. Fox (ed.), The Flow of Life: Essays on eastern Indonesia, Harvard University Press, Cambridge, Mass., pp. 231-47.

Clamagirand, B. 1982, Marobo: Une société ema de Timor, Langues et Civilisation de L'Asie du Sud-Est et du Monde Insulindien 12, SELAF, Paris.

Felgas, Hélio A. Esteves 1956, Timor Português, Agência Geral do Ultramar, Divisâo de Publicações e Biblioteca, Lisboa.

Fox, J. J. 1980a, 'Models and metaphors: comparative research in eastern Indonesia', in J. J. Fox (ed.), The Flow of Life: Essays on eastern Indonesia, Harvard University Press, Cambridge, Mass., pp. 327-33.

Fox, J. J. (ed.) 1980b, The Flow of Life: Essays on eastern Indonesia, Harvard University Press, Cambridge, Mass.

Fox, J. J. 1988, Origin, descent and precedence in the study of Austronesian societies, Public lecture in connection with De Wisselleerstoel Indonesische Studien, 17 March, Leiden University, Netherlands.

Fox, J. J. 1989, 'Category and complement; Binary ideologies and the organization of dualism in eastern Indonesia', in D. Maybury-Lewis and U. Almagor (eds), The attraction of opposites; Thought and society in the dualistic mode, University of Michigan Press, Ann Arbor, pp.33-56.

Fox, J. J. (ed.) 1993a, Inside Austronesian Houses: Perspectives on domestic designs for living, The Australian National University, Canberra.

Fox, J. J. 1993b, 'Comparative perspectives on Austronesian houses; an introductory essay', in J. J. Fox (ed.), Inside Austronesian Houses: Perspectives on domestic designs for living, Research School of Pacific Studies, The Australian National University, Canberra, pp. 1-23.

Fox, J. J. 1994, 'Origin structures and systems of precedence in the comparative study of Austronesian societies', in P. J. K. Li, Cheng-hwa Tsang, Ying-kui 
Huang, Dah-an Ho and Chiu-yu Tseng (eds), Austronesian Studies Relating to Taiwan, Symposium Series of the Institute of History and Philology, Academia Sinica 3, Taipei, pp. 27-57.

Fox, J. J. 1995, 'Austronesian societies and their transformations', in P. Bellwood, J. J. Fox and D. Tyron (eds), The Austronesians: Historical and comparative perspectives, Department of Anthropology, Research School of Pacific and Asian Studies, The Australian National University, Canberra, pp. 214-28.

Fox, J. J. 1996a, 'Introduction', in James J. Fox and Clifford Sather (eds), Origins, Ancestry and Alliance: Explorations in Austronesian ethnography, Department of Anthropology, Comparative Austronesian Project, Research School of Pacific and Asian Studies, The Australian National University, Canberra, pp. $1-17$.

Fox, J. J. 1996b, 'The transformation of progenitor lines of origin: patterns of precedence in eastern Indonesia', in James J. Fox and Clifford Sather (eds), Origins, Ancestry and Alliance: Explorations in Austronesian ethnography, Department of Anthropology, Comparative Austronesian Project, Research School of Pacific and Asian Studies, The Australian National University, Canberra, pp. 130-53.

Fox, J. J. (ed.) 1997, The Poetic Power of Place: Comparative perspectives on Austronesian ideas of locality, Department of Anthropology, Comparative Austronesian Project, Research School of Pacific and Asian Studies, The Australian National University, Canberra.

Fox, J. J. (ed.) 1999, 'Precedence in [ractice among the Atoni Pah Meto of Timor', in L. V. Aragon and S. Russell (eds), Structuralism's Transformations: Order and revisions in Indonesia and Malaysia, Center for Southeast Asian Studies, Arizona State University, Tucson, pp. 1-36.

Fox, J. J. 2000, 'Tracing the path, recounting the past: historical perspectives on Timor', in Out of the Ashes: Destruction and reconstruction of East Timor, Crawford House, Adelaide, pp. 1-29.

Fox, J. J. and Sather, C. (eds) 1996, Origins, Ancestry and Alliance: Explorations in Austronesian ethnography, The Australian National University, Canberra.

Graham, P. 1991, To follow the blood: the path of life in a domain of eastern Indonesia, PhD thesis, The Australian National University, Canberra.

Grimes, B. 1990, The return of the bride: affiliation and alliance in Buru, Master thesis, The Australian National University, Canberra. 
Hicks, D. 1986, 'The relationship terminology of the Ema', Sociologus, vol. 36, pp. 162-71.

Lewis, E. D. 1988, People of the Source: The social and ceremonial oder fo Tana Wai Brama on Flores, Verhandelingen 135, KITLV, Dordrecht, The Netherlands.

McWilliam, A. 1989, Narrating the path and the gate: place and precedence in southwest Timor, PhD thesis, The Australian National University, Canberra.

McWilliam, A. 1997, 'Mapping with metaphor: cultural topographies in West Timor', in James J. Fox (ed.), The Poetic Power of Place: Comparative perspectives on Austronesian ideas of locality, Department of Anthropology, Comparative Austronesian Project, Research School of Pacific and Asian Studies, The Australian National University, Canberra, pp. 103-15.

Molnar, A. K. 2004, 'An anthropological study of Atsabe perceptions of Kolimau 2000: a new East Timorese religious cult or internal security problem', Anthropos, vol. 99, pp. 365-79.

Molnar, A. K. 2005, 'East Timor religions', in Thomas Riggs (ed.), Worldmark Encyclopedia of Religious Practices, The Gale Group, Montana.

Molnar, A. K. 2006, 'Died in the service of Portugal: legitimacy of authority and dynamics of group identity among the Atsabe Kemak in East Timor', Journal of Southeast Asian Studies, vol. 37, no. 2, pp. 335-55.

Molnar, A. K. 2009, Timor Leste: Politics, history, and culture, Contemporary Southeast Asia Series, Routledge, London and New York.

Reuter, T. A. 2006a, 'Land and territory in the Austronesian world', in Thomas A. Reuter (ed.), Sharing the Earth, Dividing the Land: Land and territory in the Austronesian world, ANU E Press, Canberra, pp. 11-38.

Reuter, T. A. (ed.) 2006b, Sharing the Earth, Dividing the Land: Land and territory in the Austronesian world, ANU E Press, Canberra.

Sherlock, K. 1983, East Timor: liurais and chefes de suco-indigenous authorities in 1952, Unpublished manuscript, Darwin.

Vischer, M. P. 1992, Children of the black Patola stone: origin structures in a domain on Palu'e Island, eastern Indonesia, PhD thesis, The Australian National University, Canberra.

Vischer, M. P. (ed.) 2009, Precedence: Social differentiation in the Austronesian world, ANU E Press, Canberra. 